\title{
Process of Recruitment \& Selection in Havelock Holiday Beach Resort
}

\author{
R. Ramamoorthy, K. Venkatraman, A. Arunya
}

\begin{abstract}
Better enrollment and decision methodology realize improved legitimate outcomes. With reference to this one of a kind circumstance, the investigation paper entitled Recruitment and Selection has been set up to put a light on Recruitment and Selection process. The essential objective is to perceive general practices that affiliations use to enlist and pick delegates and, to choose how the selection and decision practices impact progressive outcomes at SMC Global Securities Ltd. The assessment framework associated is the exploratory. The data was accumulated through all around composed reviews. The wellspring of data was both fundamental and discretionary. Test size was 30. Data examination has been done with the help of SPSS programming. The association considered portals the most noteworthy method of getting delegates. The delegates working in the association consider the laborer references are one of the most trustworthy wellspring of obtaining the new agents. Association reliably takes in idea the cash sparing bit of leeway extent.
\end{abstract}

Keywords: Recruitment, Selection, Reference, Interview, Hiring, Performance.

\section{INTRODUCTION}

\section{Recruitment}

Meaning of Recruitment:

Enrollment intends to gauge the accessible opportunities and to make reasonable game plans for their determination and arrangement[1],[3],[5]. Enrollment is comprehended as the way toward scanning for and getting candidates for the employments, from among whom the opportune individuals can be chosen[2 ],[4],[6].

\section{Importance of Recruitment:}

- Determine the present and future prerequisites of association on combination with its staff arranging and employment examination exercises.

- Increase the pool of employment competitors at least expense.

\section{Recruitment Process:}

The procedure includes five interrelated stages:

- Stage 1: Recruitment Planning:

Revised Manuscript Received on July 22, 2019.

Mr. R. Ramamoorthy, Department of MBA, Bharath Institute of Higher Education and Research, Chennai, India.

Email: ramamoorthy0071@gmail.com

K. Venkatraman, Department of Civil Engineering, Bharath Institute of Higher Education and Research, Chennai, India.

Email: venkatraman.civil@bharathuniv.ac.in

A. Arunya, Department of Civil Engineering, Bharath Institute of Higher Education and Research, Chennai, India. Email: arunyaaaa@gmail.com
- Stage 2: Strategy Development

- Stage 3: Searching

- Stage 4: Screening.

- Stage 5: Evaluation and Control

The Selection Process of Havelock island beach resort: Initial screening of interviews

Completion of application formsEmployment tests: Interview

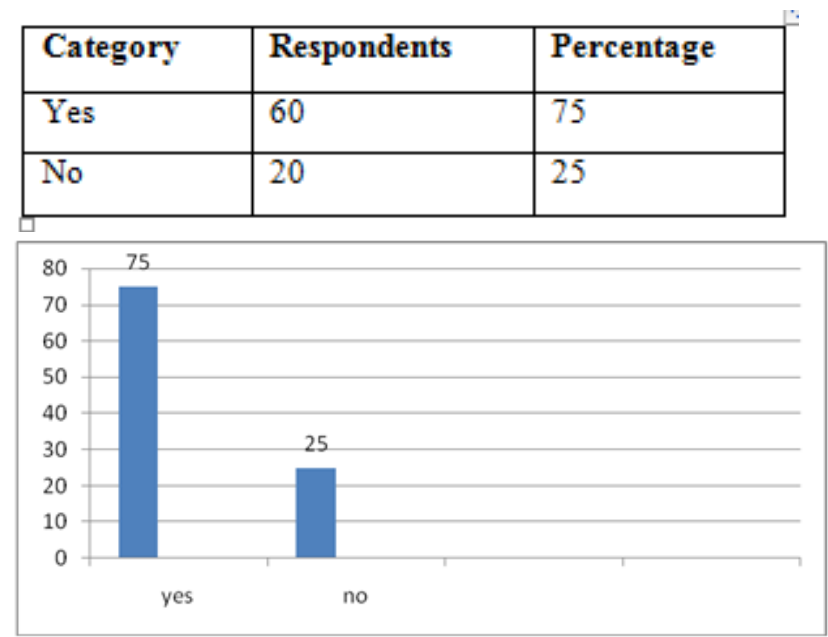

Interpretation:

The above table shows that $75 \%$ of the employees feel that the organization is doing timeliness recruitment and selection process and rest of $25 \%$ feels that the organization is not doing timeliness recruitment and selection process.

\section{RESULTS}

- The association havelock island shoreline resort has a not too bad enlistment procedure to ensure that the association gets the most sensible plausibility for the particular occupation[7],[9],[11].

- For senior positions, the HR Manager lean towards re-appropriating to work experts as they would have an increasingly broad database of experienced agents scanning for an occupation change or higher post with progressively noteworthy remunerations[8],[10],[12].

- Due to time confinements looked by the HR Department, the action openings are every so often filled by redistributing the requirements to work specialists.

- Existing present specialists are drawn closer to make Referrals when an occupation opening rises, with the objective that the contracting technique is less monotonous and incorporates no costs.

- The work opening may be made in light of debilitating, when delegates go searching 
for better occupations or associations, which offer progressively noteworthy remunerations.

- For lower level occupations, contenders are picked honestly or through referrals.

- Campus enrollments are very few.

- The genuine properties that are considered before short-posting a candidate are capacity, experience, attitude and particular scope of capacities[20],[22], [24].

\section{DISCUSSIONS}

- The association needs to use every available datum and techniques open to them including the more regular contraptions of common sense and down to earth knowledge when choosing the benefit enrolling choices for available chances[25],[27],[29].

- The association should peer inside before getting any external enlistment strategies.

- Have an indisputable perception of the present business focus including pay, capacities lacks clarifications behind contender to join the association.

- There should an other utilizing process for opening of different classes.

- There should be occupation profile or set of working duties regarding every movement essential.

- There should be an obvious perception of the best procedures for attracting agents, with better pay offers appeared differently in relation to contenders.

- The existing staff should present engaging upkeep measures and making creative and imaginative getting ready tasks to keep them prodded and secured.

- The association should review enrollment process yearly.

\section{CONCLUSION}

Choosing can never again be restricted to the standard ways. With the war of capacity raising, organizations are extending their range anyway innovative channels. Static enlistment never again takes care of business in the present setting of cost suitability and viability[26],[28],[30]. HR specialists have a noteworthy commitment to utilize a best contender from the open sources discussed previously. At the same time, one must be cost mindful. No methodology is done without an evaluation of its flourishing. Occupation passages for laborers of amazing outside selection techniques. Most affiliations have started using development to screen resumes, channel competitors and gather database for at some point later. In perspective on each available datum, a perfect, pragmatic, contrasting and adaptable enlistment strategy or reasoning for enrollment can be met up at. Inside sourcing should in like manner be done by fixing off the action post with a fitting inside candidate[31],[33]. Surrendered individuals could be given some development to finish the capacity honorably, as they would have significant lots of experience. There should be reengineering structures,

intensifying usage of advancement to diminish costs and experience every wellspring of enrollment viably, all assessments and referrals are to be used to get best results as they are the most.

\section{REFERENCES}

1) BharthVajan R., Ramachandran S.,Psychographic dimensions of training,2016,International Journal of Pharmacy and Technology,V-8,I-4,P-23727-23729

2) Balakrishnan P., Bharthvajan R.,A study on human resource planning in hospitals in Chennai City,2014,International Journal of Applied Engineering Research,V-9,I-22,P-7503-7507

3) Priyadarsini P., Bharthvajan R.,Role of emotional intelligence training programme in reducing the stress of the nurses,2014,International Journal of Applied Engineering Research,V-9,I-22,P-7411-7421

4) Kerinab Beenu G., Bharthvajan R.,Empirical analysis on the cosmetic buying behavior of young women in South India,2014,International Journal of Applied Engineering Research,V-9,I-22,P-7361-7366

5) Balakrishnan P., Bharthvajan R.,Whistling in the wind,2014,International Journal of Applied Engineering Research,V-9,I-22,P-7586-7593

6) Krishnan B., Peter M.,Health hazards of Indian Bpo employee-an alarming issue,2014,International Journal of Applied Engineering Research,V-9,I-22,P-7336-7341

7) Kerinab Beenu G.H., Peter M.,Role of insurance in economic development,2014,International Journal of Applied Engineering Research,V-9,I-22,P-7532-7539

8) Balakrishnan P., Peter M., Priyadarsini P.,Efficiency of safety measures for wellbeing of employees in manufacturing industry,2014,International Journal of Applied Engineering Research,V-9,I-22,P-7376-7382

9) Anbarasi M., Praveen Kumar S.,Online sales promotions of herbal products and its effectiveness towards tanisha.com,2019,Indian Journal of Public Health Research and Development,V-10,I-1,P-195-200

10) Anbarasi M., Praveen Kumar S.,Various online marketing and promotions strategies to improve the validation towards the organic products in the pharmaceutical sectors,2019,Indian Journal of Public Health Research and Development, V-10,I-1,P-263-269

11) Loganathan R., Praveen Kumar S.,Grievance handling a key factor for solving issues of employees in an organization,2014,International Journa of Applied Engineering Research,V-9,I-22,P-7483-7491

12) Loganathan R., Praveen Kumar S.,Study on preference of private label brands in super and Hypermarkets,2014,International Journal of Applied Engineering Research,V-9,I-22,P-7327-7335

13) Smitha M., Praveen Kumar S.,Understanding stress and its managementamong the nurses in Chennai city,2014,International Journal of Applied Engineering Research,V-9,I-22,P-7560-7565

14) Kerinab Beenu G.H., Praveen Kumar S.,A study on the investment behavior of Chennai investors in mutual fund schemes,2014,International Journal of Applied Engineering Research,V-9,I-22,P-7520-7525

15) Loganathan R., Praveen Kumar S.,Retention strategies key for organizational productivity,2014,International Journal of Applied Engineering Research,V-9,I-22,P-7443-7447

16) Pavithra J., Ganesan M., Brindha G.,State wise analysis of microfinance sector in India,2016, International Journal of Pharmacy and Technology,V-8,I-4,P-23417-23432

17) Pavithra J., Ganesan M.,A comparative study on microfinance in India and abroad,2016,International Journal of Applied Business and Economic Research,V-14,I-8,P-5471-5476

18) Pavithra J., Ganesan M.,A study on awareness and impact of micro-financial schemes,2016,International Journal of Applied Business and Economic Research,V-14,I-8,P-5449-5460

19) Senthilmurugan P., Pavithra J.,Consumer preference towards organised retailing with reference to Big Bazaar,2014,International Journal of Applied Engineering Research,V-9,I-22,P-7469-7475

20) Senthilmurugan P., Pavithra J.,Implication of social media marketing in growing healthcare industry,2014,International Journal of Applied Engineering Research,V-9,I-22,P-7448-7456

21) Loganathan R., Pavithra J.,Consumer perception towards private label brand over other brands in super markets and hypermarkets,2014,International Journal of Applied Engineering Research,V-9,I-22,P-7355-7360

22) Kerinab Beenu G., Pavithra J.,Tradeâ€"off between liquidity and profitability in logistics industry,2014,International Journal of Applied Engineering Research,V-9,I-22,P-7398-7401 
23) Kerinab Beenu G., Pavithra J.,A study on the prospective consumerâ€ $€^{\mathrm{TM}_{S}}$ perception towards utility cars in Chennai city,2014,International Journal of Applied Engineering Research,V-9,I-22,P-7526-7531

24) Pavithra J., Dilli Babu P., Ambuli T.V.,A study on budgetary control at Maruti Service Masters, Chennai,2014,International Journal of Applied Business and Economic Research,V-12,I-2,P-151-161

25) Pavithra J., Dilli Babu P., Ambuli T.V.,A study on customer satisfaction of retro Garments Pvt Ltd, Chennai,2014,International Journal of Applied Business and Economic Research,V-12,I-2,P-381-391

26) Kerinab Beenu G.H., Pavithra J., Senthilmurugan P.,A study on the influence of promotional activities for TATA ARIA among consumers in Chennai,2014,International Journal of Applied Engineering Research,V-9,I-22,P-7572-7578

27) Vijayaragavan S.P.,An investigative expert that's general FBG sensors,International Journal of Mechanical Engineering and Technology,V-8,I-8,PP-1500-1505,Y-2017

28) Vijayaragavan S.P.,Equalization routing protocol for Wi-Fi sensor strategy,International Journal of Mechanical Engineering and Technology,V-8,I-8,PP-1662-1666,Y-2017

29) Karthik B., Kiran Kumar T.V.U., Vijayaragavan P., Bharath Kumaran E.,Design of a digital PLL using 0.35 $\hat{\mathrm{I}}^{1 / 4 \mathrm{~m}}$ CMOS technology,Middle East Journal of Scientific Research,V-18,I-12,PP-1803-1806,Y-2013

30) Kanniga E., Selvaramarathnam K., Sundararajan M.,Kandigital bike operating system,Middle - East Journal of Scientific Research,V

31) Jasmin M., Vigneshwaran T., Beulah Hemalatha S.,Design of power aware on chip embedded memory based FSM encoding in FPGA,International Journal of Applied Engineering Research,V-10,I-2,PP-4487-4496,Y-2015

32) Jasmin M.,Optimization techniques for low power VLSI circuits,Middle East Journal of Scientific Research,V-20,I-9,PP-1082-1087,Y-2014

33) Jasmin M., Vigneswaran T.,Fuzzy controller for error control of on - Chip communication,2017 International Conference on Algorithms, Methodology, Models and Applications in Emerging Technologies, ICAMMAET 2017,V-2017-January,I-,PP-1-5,Y-2017

\section{AUTHORS PROFILE}

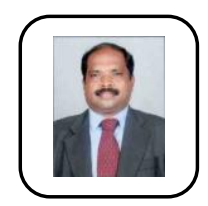

Mr. R. Ramamoorthy Assistant Professor, Department of MBA, Bharath Institute of Higher Education and Research, Chennai, India.

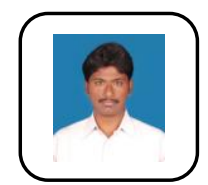

K. Venkatraman Assistant Professor, Department of Civil Engineering, Bharath Institute of Higher Education and Research, Chennai, India.

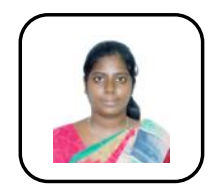

A. Arunya Assistant Professor, Department of Civil Engineering, Bharath Institute of Higher Education and Research, Chennai, India. 